From Table $V$ it will be noted that the first cone was found the most satisfactory for all purposes. The time factor as compared with the Gooch and filter paper was reduced considerably without reducing the accuracy to any appreciable extent.

The cleansing of the filter may be readily accomplished by inverting it on a rubber cork and reversing the flow, as is illustrated in Fig. 4.

On the whole the new conical filters proved to be far superior to those ordinarily used.

\begin{tabular}{|c|c|c|c|c|c|c|c|}
\hline \multirow[b]{2}{*}{ Amount found. } & \multicolumn{3}{|c|}{$\mathrm{Al}_{2} \mathrm{O}_{3}$} & \multicolumn{2}{|c|}{$\mathrm{AgCl}$} & \multicolumn{2}{|c|}{$\mathrm{HaSO}_{4}$} \\
\hline & $\begin{array}{l}\text { Weight. } \\
\text { Gram. }\end{array}$ & $\begin{array}{l}\text { Differ- } \\
\text { ence. } \\
\mathrm{Mg} .\end{array}$ & $\begin{array}{c}\text { Time } \\
\text { required. } \\
\text { Min. }\end{array}$ & $\begin{array}{l}\text { Wt. } \\
\text { Gram. }\end{array}$ & $\begin{array}{c}\text { Differ- } \\
\text { ence. } \\
\mathrm{Mg} \text {. }\end{array}$ & $\begin{array}{l}\text { Weight. } \\
\text { Gram. }\end{array}$ & $\begin{array}{l}\text { Differ- } \\
\text { ence. } \\
\mathrm{Mg} \text {. }\end{array}$ \\
\hline By calculation.. & 0.0500 & & & 0.1687 & & 0.1349 & \\
\hline With cone 320. & 0.0510 & +1.0 & 2.5 & 0.1650 & -3.7 & ). 1329 & -2.0 \\
\hline With cone 321. & 0.0510 & +1.0 & 2.0 & 0.1644 & -4.3 & 1). 1331 & -1.8 \\
\hline $\begin{array}{l}\text { With cone } 327 . \\
\text { With cone } 321\end{array}$ & 0.0502 & +0.2 & 2.0 & 0.1651 & -3.6 & 0.1331 & -1.8 \\
\hline $\begin{array}{l}+ \text { paper.... } \\
\text { with cone } 322\end{array}$ & 0.0522 & +2.2 & 45.0 & 0.1647 & -4.0 & 0.1332 & -1.7 \\
\hline $\begin{array}{l}+ \text { paper.... } \\
\text { With asbestos }\end{array}$ & 0.0522 & +2.2 & 30.0 & 0.1662 & -2.5 & 0.1327 & -2.2 \\
\hline Gooch...... & 0.0536 & +3.6 & 11.0 & 0.1650 & -3.7 & 0.1328 & -2.1 \\
\hline With paper filter & ro.0519 & +1.9 & 9.0 & 0.1642 & -4.5 & D. 1349 & 0.0 \\
\hline
\end{tabular}

The authors have endeavored to point out the advantages accruing from the use of a filter of this improved type, the value and superiority of which have already been fully demonstrated by their successful application, under varying conditions, in general laboratory operation.

RESEARCIF IABORATORIES, NORTON COMPANY, WORCES'TER, MASS.

CALCULATION OF SULPHURIC ACID STOCK BY APPROXIMATE 25. ACCURATE METHODS. A SPECIAL SLIDE RULE FOR THIS PURPOSE.

By H. C. MOORE.

Received May 25, 1912.

When taking periodical inventories of the amount of sulphuric acid stock on hand in the numerous tanks and chambers around a sulphuric acid plant it is customary to test the acid in each tank for density, in terms of degrees Baumé, and also for temperature. The depth of the acjd is also measured, and knowing the dimensions of the tanks and chambers it is a simple matter to calculate the number of cu. ft. of acid in each container.

The next step is to calculate, from the data thus obtained, the acid in each lot to the same basis, as, for instance, to the basis of its equivalent in terms of $50^{\circ} \mathrm{B}, 60^{\circ} \mathrm{B}$. or $66^{\circ} \mathrm{B}$. acid at $60^{\circ} \mathrm{F}$. The whole amount of acid on hand is then determined in terms of one grade.

Among fertilizer factories it is customary to calculate a1l acid in terms of $50^{\circ} \mathrm{B}$. acid at $60^{\circ} \mathrm{F}$. Tables. which are available, make it possible to determine the number of pounds of $50^{\circ} \mathrm{B}$. acid equivalent to a cu. ft. of acid of any density and temperature. The tables as adopted by the Manufacturing Chemists' Association of the United States in I004 are generally used as a basis for making all calculations.

Now it is no short task for the superintendent or the chemist of a sulphuric acid plant to take a long row of figures, which represent the density and temperature of the acid in the numerous tanks and chambers. and calculate correctly from this data the exact equivalent in terms of $50^{\circ} \mathrm{B}$. acid, unless a very voluminous set of tables has been especially prepared for this purpose. By calculating correctly the writer means that exact corrections are made for density and temperature instead of the rough or approximate corrections ordinarily made.

If, however, one is content when taking the acid inventory, to record the density reading to the nearest even degree Baumé and the temperature to the nearest ten degrees Fahrenheit, then the problen is not such a long task, especially if one also assumes that one cu. $\mathrm{ft}$. of acid testing, say, $5^{\circ} \mathrm{B}$. at a temperature from $90^{\circ} \mathrm{F}$. to $110^{\circ} \mathrm{F}$. is equivalent to one cu. ft. of acid testing $53^{\circ} \mathrm{B}$. at $60^{\circ} \mathrm{F}$. If all of these assumptions are made the summary of the acid inventory becomes very simple indeed, and if a few simple sets: of tables have, been compiled, practically no calculations are necessary. Such a method of figuring is not correct, however, and the error will vary, being greater for acid at higher temperatures.

Acid testing, say, $50^{\circ} \mathrm{B}$. at $130^{\circ} \mathrm{F}$. when cooled to $60^{\circ} \mathrm{F}$. would have a density of $53.9^{\circ} \mathrm{B}$., but one $\mathrm{cu}$. ft. of this acid at $30^{\circ} \mathrm{F}$. would have a volume of less than one cu. ft. if cooled to $60^{\circ} \mathrm{F}$. while the shrinkage amounts to about 2.25 per cent., or an error too great to be overlooked.

By mentioning the above incorrect methods of calculating sulphuric acid stock, the writer does not wish to infer that such methods are generally used, but has simply referred to some methods which have come to his knowledge both by hearsay and observation. He has also heard chemists remark that they were not sure they were making their claculations with absolute correctness.

There is another slight crror which the writer has often observed, which, however, is scarcely appreciable. In the tables adopted by the Manufacturing Chemists" Association, in 1904 , will be found a table marked "Allowance for Temperature." This table indicates the correction necessary to apply to Baumc readings to correct from one temperature basis to another. The allowance for temperature for $50^{\circ} \mathrm{B}$. acid is $0.028^{\circ} \mathrm{B}$. and for $60^{\circ} \mathrm{B}$. acid is $0.026^{\circ} \mathrm{B}$., for each degree Fahrenheit. Therefore, acids of densities between these limits probably have an allowance-for-temperature value proportionately between the values given. By interpolation the allowance for $52^{\circ} \mathrm{B}$. acid would be $0.0276^{\circ} \mathrm{B}$. and for $54^{\circ} \mathrm{B}$. would be $0.0274^{\circ} \mathrm{B}$. for $\mathrm{I}^{\circ} \mathrm{F}$.

Take the case of acid testing $52.0^{\circ} \mathrm{B}$. at $130^{\circ} \mathrm{F}$. This ac $\mathrm{d}$ when cooled to $60^{\circ} \mathrm{F}$. would be about $54^{\circ} \mathrm{B}$, and, therefore, the value $0.0274^{\circ} \mathrm{B}$. for $\mathrm{I}^{\circ} \mathrm{F}$. should be applied, and 52.0 plus $(70 \times 0.0274)=53.9^{\circ} \mathrm{B}$. at $60^{\circ} \mathrm{F}$. These allowance-for-temperature values were determined, as the writer understands from the original paper on this work, by heating the acicl, starting at $60^{\circ} \mathrm{F}$. and noting the density variation for rise in temperature. To further illustrate this 
point, assume acid testing $50.00^{\circ} \mathrm{B}$. at $60^{\circ} \mathrm{F}$. Calculating the density of this acid if heated to $203^{\circ} \mathrm{F}$. we get $54.00^{\circ} \mathrm{B}$. Now suppose we start with acid at $54.00^{\circ} \mathrm{B}$. and $203^{\circ} \mathrm{F}$. and calculate it back to the basis of $60^{\circ} \mathrm{F}$. by applying the temperature allowance of $0.0274^{\circ} \mathrm{B}$. for $\mathrm{r}^{\circ} \mathrm{F}$., which, as above mentioned, would be the temperature allowance interpolated for $54^{\circ} \mathrm{B}$. acid, and we would get $50.08^{\circ} \mathrm{B}$. at $60^{\circ} \mathrm{F}$. The discrepancy, of course, is slight. yet it simply points out a very common error which the writer has observed.

To indicate the error in assuming that one cu. ft. of acid at a temperature above $60^{\circ} \mathrm{F}$. is equivalent to one cu. ft. of the acid calculated to its density at $60^{\circ} \mathrm{F}$. the following table has been prepared:

$\begin{array}{ll}50^{\circ} \mathrm{B} \text {. at } 130^{\circ} \mathrm{F} .=51.93^{\circ} \mathrm{B} \text {. at } 60^{\circ} \mathrm{F} \text {. } & \begin{array}{c}\text { Contraction } \\ \text { error. }\end{array} \\ 50^{\circ} \mathrm{B} \text {. at } 140^{\circ} \mathrm{F}=52.21^{\circ} \mathrm{B} \text {. at } 60^{\circ} \mathrm{F} \text {. } & 2.32 \\ 51^{\circ} \mathrm{B} \text {. at } 100^{\circ} \mathrm{F}=52.10^{\circ} \mathrm{B} \text {. at } 60^{\circ} \mathrm{F} \text {. } & 1.17 \\ 51^{\circ} \mathrm{B} \text {. at } 90^{\circ} \mathrm{F}=51.83^{\circ} \mathrm{B} \text {, at } 60^{\circ} \mathrm{F} \text {. } & 0.88 \\ 49^{\circ} \mathrm{B} \text {. at } 170^{\circ} \mathrm{F} .=52.04^{\circ} \mathrm{B} \text {. at } 60^{\circ} \mathrm{F} \text {. } & 3.16 \\ 48^{\circ} \mathrm{B} \text {. at } 200^{\circ} \mathrm{F} .=51.86^{\circ} \mathrm{B} \text {. at } 60^{\circ} \mathrm{F} \text {. } & 3.98 \\ 47^{\circ} \mathrm{B} \text {. at } 240^{\circ} \mathrm{F} .=52.04^{\circ} \mathrm{B} \text {, at } 60^{\circ} \mathrm{F} \text {. } & 5.14\end{array}$

If the amount of acid used per charge when making acid phosphate is measured and the proper corrections are not made for density and temperature, the error will be greater the higher the temperature of the acid used in mixing. Further, if the amount of acid used per week is computed from records thus obtained the error may be considerable We might assume that the error in calculating the acid in the tanks and chambers is fairly constant from one inventory to another, which assumption would be reasonably correct providing the stock carried in the tanks and chambers remains about constant with small variations in density and temperature.

The writer wishes to state at this point that he is not unmindful of the great difficulty, rather the impossibility, of securing a sample of the acid in the tanks, and especially in the chambers, which is exactly representative of all the acid in each lot. Therefore, the density and temperature of each lot of acid can be only approximately determined. If, however, the acid in each tank and chamber is tested at the same point and in the same manner each time the error will be reasonably constant and the appreciable error, therefore, unless the proper corrections are made as regarding density and temperature, is made in calculating the amount of acid used per week or similar period.

If the acid used at the mixer (acid phosphate) has a temperature of $\mathrm{I} 30^{\circ} \mathrm{F}$, the error, resulting by making the incorrect allowance for density and temperature as before described, will amount to about 2 per cent. In other words, the acid department gets credit for 2 per cent. more acid than actually made and the acid phosphate department gets the loss, which is included in the shrinkage allowed.

The writer has known of cases where such errors when unearthed have helped to explain why some acid plants could often get a yield of from 4.95 to $5.201 \mathrm{bs}$. of $50^{\circ} \mathrm{B}$. acid per pound of sulphur burned.

It might be well to give here two methods by which correct results may be obtained when calculating acid.
These methods will not be new to many and yet may be of value to others.

Assume that we have one cu. ft. of sulphuric acid testing $51.0^{\circ} \mathrm{B}$. at $100^{\circ} \mathrm{F}$. and wish to find its equivalent in terms of $50^{\circ} \mathrm{B}$. acid at $60^{\circ} \mathrm{F}$. First by reference to the tables and making the calculations before described, we calculate that this acid would have a density of $52 . \mathrm{I}^{\circ} \mathrm{B}$, at $60^{\circ} \mathrm{F}$. From this point the calculation may be made by two methods:

Method I:

I cu. ft. $51.0^{\circ} \mathrm{B}$, acid weighs $96.21 \mathrm{lbs}$. (from table)

I cu. ft. $52.1^{\circ}$ B. acid weighs $97.35 \mathrm{lbs}$. (from table)

$96.2 \mathrm{I} / 97.35=0.988 .3 \mathrm{cu}$. ft. $=$ volume which the cu. ft. of $5 \mathrm{I}^{\circ} \mathrm{B}$. acid at $100^{\circ} \mathrm{F}$. would have if cooled to $60^{\circ} \mathrm{F}$.

I cul ft. $52.1^{\circ} \mathrm{B}$. acid at $60^{\circ} \mathrm{F} .=102.20 \mathrm{lbs}$. $50^{\circ} \mathrm{B}$. acid (interpolated from tables).

Therefore, $0.9883 \times 102.20=101.00 \mathrm{lbs} .50^{\circ} \mathrm{B}$ acid at $60^{\circ} \mathrm{F}$.

Method II:

I cu. ft. $5^{\circ} \mathrm{B}$. acid weighs 96.2 I lbs.

$52 . \mathrm{I}^{\circ} \mathrm{B}$. acid at $60^{\circ} \mathrm{F} .=104.98$ per cent. of $50^{\circ} \mathrm{B}$. acid at $60^{\circ} \mathrm{F}$. (interpolated from tables).

104.98 per cent. of $96.2 \mathrm{I}=10 \mathrm{I} .00 \mathrm{lbs} .50^{\circ} \mathrm{B}$. acid at $60^{\circ} \mathrm{F}$.

Method I though longer than Method II is interesting in that it will indicate the shrinkage in volume which would result if the acid were cooled to $60^{\circ} \mathrm{F}$.

The writer has seen private sets of tables which. have been compiled and which make all necessary corrections, thus greatly shortening the time required in making the calculations of acid of different densities and temperature to one basis. At one time he also prepared such a set of tables, but the time required was about three weeks, and the tables then were not thoroughly' complete but fulfilled practically all the requirements of the plants at which they were used.

It then occurred to me that some simple means might be found for making all such corrections and calculations in a short time, so my efforts were directed to the problem of determining if it were possible to design a special slide rule by means of which all calculations might be made. After spending considerable time a design for such a slide rule was finally devised and after making many hundred calculations the full details and specifications were worked out. Models were then prepared, which proved that the rule would permit accurate calculations to be made.

By use of this slide rule corrections may be applied to Baumé readings for temperature, thus calculating acid of one density to corresponding density at any other temperature. This requires one adjustment only of the slide rule. Now by making one additional adjustment the final result may be read from the rule directly; that is, one cu. ft. of acid of any density and temperature can be calculated to its equivalent in terms of $50^{\circ} \mathrm{B}$. acid at $60^{\circ} \mathrm{F}$. (or in terms of $60^{\circ} \mathrm{B}$. or $66^{\circ} \mathrm{B}$. acid if desired, or in fact to any basis). Also, if desired, too lbs. of acid of any density and temperature can be calculated to its equivalent of $50^{\circ} \mathrm{B}$. acid at $60^{\circ} \mathrm{F}$. (or to any other basis desired) just as easily. 
Each case can be worked out by means of this rule in less than ten seconds, which surely allows a wonderful saving of time. The rule is based entirely on the tables of the Mantfacturing Chemists' Association of the United States, adopted rgo4, and no tables need be used in connection with the rule to give final results. runner to division 60 on Row $\mathrm{D}^{4}$. Read below on Row $E$ and $52.1^{\circ} \mathrm{B}$. is indicated as the corrected Baumé reading. Now adjust the slide so that division 50, Row $A$, and division $5 \mathrm{I}$, Row $\mathrm{B}$, are in alignment. Move the runner over the 52.1 division on Row $A$ and read under the runner on Row $C$, when 101.00 is indicated as the correct resujt.

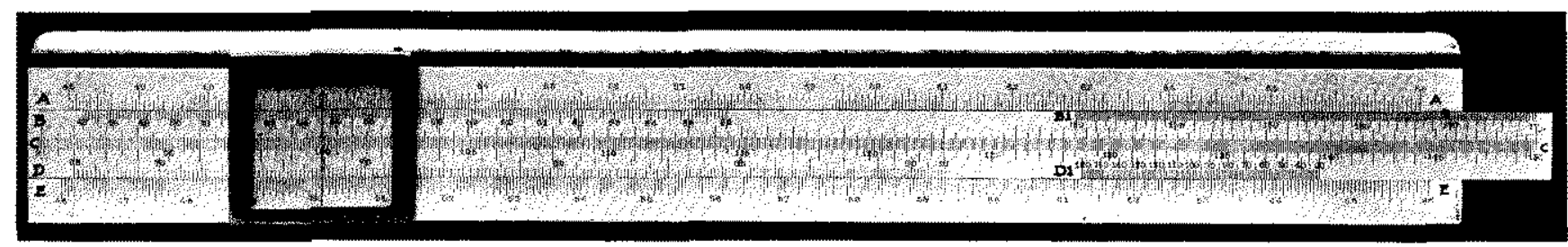

The accompanying cut shows one of these slide rules, submitted by the manufacturers as a sample. but which is not exactly correct.

The divisions on the slide rule are marked in terms of degrees Baumé. degrees Fahrenheit and pounds per cu. ft. Baumé divisions are to tenths, and in some cases to $0.05^{\circ} \mathrm{B}$. the Fahrenheit scale to ${ }^{\circ}$ and the pounds per $c u$. ft. scale to tenths of a pound per cu. ft. The latter scale can be read to within 0.0 to $0.02 \mathrm{lb}$. per cu. it. and the Baumé scale to $0.01^{\circ} \mathrm{B}$. In other words, the accuracy of results obtained by the rule are within the limits of error of reading an ordinary hydrometer divided to tenths of a degree Baumé. The scales include Baumé readings between $48^{\circ}$ and $66^{\circ} \mathrm{B}$. and from $30^{\circ}$ to $160^{\circ} \mathrm{F}$.

Referring to the rows of divisions by letters: Row $D^{\prime}$ and $E$ are used together to correct Baume readings from one temperature to another.

Row $B^{x}$ is a continuation of Row $C$, which is likewise a continuation of Row $D$. This arrangement is adopted to get all of the divisions on a $10^{\prime \prime}$ rule and yet have divisions far enough apart to permit accurate and rapid readings. The value of divisions in these rows represents pounds per cu. ft.

Row $B$ is divided in terms of weight per cu. ft. of acid of different densities. To find from this rule the weight per cu. ft. of acid of densities between the limits included, refer to the division on Row B corresponding to its Baumć reading and project on to Scale $C$, where the value for its weiglt can be directly read.

Row $\mathrm{A}$ is divided in terms of percentages. (Attention. is hereby called to the error on this row, noticeable between the 49 and 50 divisions.) To find the per cent. of one acid as compared to $50^{\circ} \mathrm{B}$. acid, adjust the slide so that the 50 division, Scale $A$, is in vertical alignment as indicated by the rumer with roo on Scale C. Now adjust the runner over the division on Row A corresponding to the density of the acid which it is desired to refer to its per cent. of $50^{\circ} \mathrm{B}$. acid and read below on scale $C$. To find the corresponding per cent. of $60^{\circ} \mathrm{B}$. acid, the operation is similar.

To calculate, for example, $x$ cu. ft. of acid testing $51.0^{\circ} \mathrm{B}$. at $100^{\circ} \mathrm{F}$. to its equivalent in terms of $50^{\circ} \mathrm{B}$. acid at $60^{\circ} \mathrm{F}$. by this rule, the procedure is as follows:

line up, by means of the rumer, division roo on Row $D^{x}$ and division 5 r.o on Row $\mathrm{I}$. Now move
Such a slide rule would be of very great value to a chemist or superintendent who has to calculate sulphuric acid stock, and also to a broker who buys and sells acid.

ARMOUR FerTILIZER WORKs, ATLANTA, GA.

\section{A SIMPLE AND INEXPENSIVE CONDUCTIVITX CELL.}

By CARL. A. NowaK.

Received June $8,1912$.

Unable to obtain a standard conductivity cell from any of the chemical supply houses in town, and anxious to complete a series of experiments, the author undertook to construct a cell from materials available in the laboratory. This cell, although primarily intended as a makeshift until a standard cell could be obtained, gave such satisfaction, that, for the experiments in hand, it proved practically equal to any of the standard cells now on the market. A brief description of the manner in which this cell was constructed may possibly be of assistance to others, who, like the author, may at some future time be dependent upon a cell of their own construction.

Before going into details it may be well to point out certain of the advantages possessed by this cell: First, It requires only $20 \mathrm{cc}$. of liquid. Socond, on account of the small volume of liquid the same is more quickly brought to the temperature of the thermostat. Third, "The cost is considerably lower than that of the cells on the market since the electrodes are made of thin platinum foil, but being concave and themselves fastened directly into the cork cover, are rigid and not easily bent out of shape or otherwise injured, thereby causing a change in the cell constant. Fourth, The cell constant can be adjusted to suit the requirements of the test, either by varying the height of the liquid or by reducing the electrode surfaces. The thermometer is directly in the path of the electrodes, and the two loops of platinum foil make it very easy to connect the cell to the circuit. The complete cell can be easily constructed in about one hour from materials to be found in almost every laboratory, and at a low cost.

Fig. I is a photograph of the cell and Fig. 2, diagrams giving better the details of construction.

A wide mouthed glass bottle $\mathrm{I} / \mathrm{a}$ inches in diameter and $2 \% /$ inches high was used for the cell body. A 